\title{
As relações de poder no Aterro Sanitário Metropolitano Oeste de Caucaia, Estado do Ceará, Brasil
}

\section{Maria Laudecy Ferreira de Carvalho ${ }^{1, *}$, Joel Silva dos Santos $^{1}$, Luan Gomes dos Santos de Oliveira ${ }^{2}$ e Ana Bárbara de Araújo Nunes ${ }^{3}$}

\author{
${ }^{1}$ Universidade Federal da Paraíba. Programa de Pós-Graduação em \\ Desenvolvimento e Meio Ambiente (PRODEMA). Campus I. João Pessoa-PB, Brasil \\ (CEP 58051-900). *E-mail: laudecyferreira@gmail.com. \\ ${ }^{2}$ Universidade Federal de Campina Grande. Centro de Ciências Jurídicas e Sociais. \\ Sousa-PB, Brasil (CEP 58800-240). \\ ${ }^{3}$ Universidade Federal do Ceará. Departamento de Engenharia Hidráulica e \\ Ambiental. Campus do Pici. Bloco 713. Fortaleza-CE, Brasil (CEP 60440-970).
}

Resumo. Relações de poder no Aterro Sanitário Metropolitano Oeste de Caucaia no Município de Caucaia, Ceará, Brasil. A questão destacada neste artigo diz respeito às relações de poder que determinam o acesso e uso dos recursos naturais e, consequentemente, os conflitos socioambientais entre atores sociais em torno do Aterro Sanitário Metropolitano Oeste de Caucaia (ASMOC) e da Usina de Caucaia Biogás GNR Fortaleza Valorização de Biogás Ltda, ambas localizadas no Município de Caucaia, Estado do Ceará, Nordeste do Brasil, na perspectiva da Ecologia Política. Dentre os atores sociais investigados na pesquisa, destacam-se a população da comunidade do entorno, os funcionários e os gestores da usina GNR e do aterro. Vale destacar que a Ecologia Política foi utilizada enquanto chave de leitura epistemológica dos conflitos socioambientais e compreensão das relações de poder estabelecidas ao longo dessa rede de interesses diversos. Sendo assim, o objetivo central da pesquisa é averiguar as relações de poder na determinação do acesso, uso dos recursos naturais e conflitos socioambientais na área de estudo. Discute-se também as estratégias da tríade do biopoder elencada por Foucault, o psicopoder enfatizado por Byung-Chul Han e o ecopoder destacado por Enrique Leff e Juan Manuel Naredo, na tentativa de evidenciar os danos sociais e ecológicos da biosfera e como as estratégias intervêm por meio dessas relações na determinação do usufruto dos recursos naturais e suas externalidades. Trata-se de uma pesquisa baseada em revisão de literatura e análise documental, utilização da técnica da "bola de neve", realização de trabalho de campo e 10 entrevistas in loco e aplicação de 14 questionários com os atores sociais investigados. Os resultados sinalizaram que é necessário monitorar os
Recebido

$28 / 09 / 2021$

Aceito

$24 / 12 / 2021$

Publicado

$31 / 12 / 2021$

Acesso aberto

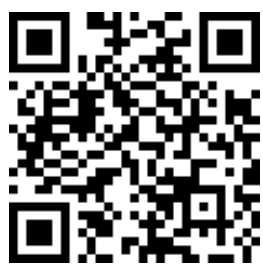

(D) 0000-0002-4868-8997

Maria Laudecy

Ferreira de Carvalho

(D) 0000-0002-8068-630X

Joel Silva dos Santos

ISSN 2359-1412/RBGAS-2021-0123/2021/8/20/25/1665

Rev. Bras. Gest. Amb. Sustent.

http://revista.ecogestaobrasil.net 
problemas e os resultados das ações humanas para que se possam perceber as mudanças e transformações que devem ser adotadas rumo à educação ambiental para as gerações do presente e futura. Conclui-se que há manutenção do poder e suas estruturas sobre os mais vulneráveis em torno dos empreendimentos estudados.

Palavras-chave: Relação de poder; Aterro Sanitário; Usina de biogás; Ecologia Política; Caucaia; Ceará; Brasil.

Abstract. Power relations at the Metropolitan Sanitary
Landfill West of Caucaia, State of Ceará, Brazil. The issue highlighted in this article concerns the power relations that determine the access and use of natural resources and, consequently, the socio-environmental conflicts between social actors in the surroundings of the Metropolitan Sanitary Landfill West of Caucaia (ASMOC) and the Usina de Caucaia Biogás GNR Fortaleza Valorização de Biogás Ltda, both located in the Municipality of Caucaia in the State of Ceará, Northeast Brazil, from the perspective of Political Ecology. Among the social actors investigated in the research, the following stand out the population of the surrounding community, employees and managers of the GNR plant and the landfill. It is worth noting that Political Ecology was used as a key to the epistemological reading of socio-environmental conflicts and understanding of the power relations established along this network of diverse interests. Thus, the main objective of the research is to investigate the power relations in determining access, use of natural resources and socio-environmental conflicts in the study area. This work also discusses the strategies of the biopower triad listed by Foucault, psychopower emphasized by Byung-Chul Han, and ecopower highlighted by Enrique Leff and Juan Manuel Naredo, in an attempt to highlight the social and ecological damage of the biosphere and how strategies intervene through these power relations in determining the use of natural resources and their externalities. This is a research based on literature review and document analysis, use of the "snowball" technique, fieldwork and 10 interviews in loco and application of 14 questionnaires with the social actors investigated. The results indicated that it is necessary to monitor the problems and results of human actions so that the changes and transformations that must be adopted towards environmental education for present and future generations can be perceived. Therefore, it is concluded that there is maintenance of power and its structures over the most vulnerable around the projects under discussion.

Keywords: Power relationship; Sanitary Landfill; Biogas plant; Political Ecology; Caucaia; Ceará; Brasil.
D) 0000-0001-6642-0006

Luan Gomes dos

Santos de Oliveira

(D) 0000-0001-6059-8540

Ana Bárbara de Araújo

Nunes 


\section{Introdução}

É pela mediação das relações de poder que as sociedades humanas produzem a realidade material e simbólica, se relacionam e nessa relação são produzidos os conflitos sociais, ambientais, políticos, econômicos e culturais. É em torno das leis, das normas e da lucratividade e das injustiças de diversas facetas que os conflitos são travados. Dessa forma, com o intuito de averiguar as relações de poder na determinação do acesso e uso dos recursos naturais entre os atores sociais do entorno, funcionários e gestores do Aterro Sanitário Metropolitano Oeste de Caucaia (ASMOC) e gestores e funcionários da usina de biogás GNR (Gás Natural Renovável) Fortaleza Valorização de Biogás LTDA, localizados no Município de Caucaia, Região Metropolitana de Fortaleza-CE (RMF), recorreu-se à Ecologia Política discutida por Martinez-Alier (2011) e Porto (2007) e às estratégias da tríade do biopoder elencado por Foucault (2018), o psicopoder enfatizado por Han (2016) e o ecopoder destacado por Leff (2014) e por Naredo (2007), assim como por contribuições sobre relação de poder em Garcia (2015), Ortiz de Landázuri (2017) e Gumbowsky et al. (2019), dentre outros.

Dessa forma, promoveu-se uma interação dos conceitos de biopoder e suas consequências na estratégia de poder do conhecimento elencado por Foucault, o termo psicopoderna perspectiva do termo de estratégia do controle da psique de Byung-Chul Hane as contribuições do termo ecopoder a partir do filósofo Enrique Leff e o economista Juan Manuel Naredo, na tentativa de evidenciar os danos sociais e ecológicos da biosfera e como as estratégias intervêm de poder na relação entre sociedade e natureza. Essa contribuição do conhecimento evidenciada por Leff e Naredo é peculiar à realidade da população do entorno do aterro sanitário e da usina. Os danos, os conflitos e os impactos socioambientais citados nesta pesquisa revelam o quanto o biopoder está presente na gestão daqueles que são proprietários do ASMOC e da Usina. Existe uma apropriação dos recursos naturais da região onde se localiza o aterro e a usina. Assim sendo, a população do entorno é excluída do uso desses recursos naturais. Essa situação pode estar presente na população do entorno do aterro sanitário ASMOC e da Usina de Biogás GNR Fortaleza, que são invisíveis dentro processo de gestão social, ou seja, falta-lhe o mínimo básico para a sua sobrevivência.

\section{As estratégias da Tríade do Biopoder (Foucault), Psicopoder (Byung- ChulHan) e o Ecopoder (Leff e Naredo)}

Para compreender como se dá essa relação do poder imprimiu-se estudos para se averiguar a vida humana e da natureza, assim sendo, parte-se do princípio das ações trinomiais bio-psico-eco com base epistemológica sobre o poder e suas estratégias na perspectiva da Economia ambiental e a economia verde de modo a contribuir positivamente nas análises ecológicas e econômicas para a melhoria da biosfera como um todo. Para o filósofo colombiano Medieta (2007), "o poder é para o sistema social o que a computação é para o sistema de computador. Ambos os casos, nenhum existe fora do que os executa".

Foucault (2018) usou o termo biopoder para explicar como acontecia o domínio do conhecimento do poder humano sobre a Biologia. Para Bazzicalupo (2016, p. 65), o poder humano de forma a "se materializar na vida política com a intenção de determinar que há um julgamento político de valor tanto para selecioná-lo quanto para melhorá-lo".

Para Foucault (1976, p. 32-33), "toda relação de exploração é principalmente uma relação política", portanto, nessa relação à pessoa está na base política e social e dentro do princípio fundamental da ética, a pessoa é tida como vítima (Foucault, 2012). Para Osório (2006), basta evidenciar de um lado a reprodução social onde é ocultado o fenômeno da exploração permanente e do outro lado o estabelecer de estratégias de dominância aparentemente livre, ou seja, trata-se de um movimento livre de mercadorias e opressor 
de pessoas de forma a roubar a criatividade, onde as pessoas tornam-se invisíveis para o sistema operacional.

\begin{abstract}
Foucault caracteriza a lei como manifestação da vontade do poder soberano. Para que a lei possa vigorar, ela precisa necessária e indispensavelmente emanar do soberano ou ser confirmada por ele. Aquele que infringe a lei ataca direta e pessoalmente a figura do soberano. Já o jurista e filósofo Giorgio Agamben, que seguiu a linha investigativa de Foucault, esclarece sobre a soberania "[...] existe uma figura-limite da vida, um limiar em que ela está, simultaneamente, dentro e fora do ordenamento jurídico, e este limiar é o lugar da soberania" (Agamben, 2002, p. 33).
\end{abstract}

Para Han (2016), por meio do psicopoder a força de vontade pessoal se estende à vontade de outras pessoas de modo que essas pessoas acolhem de forma voluntária, o que configura controlar as ações dos outros. No psicopoder o uso da motivação e otimização estimulam para o sucesso de modo a converter indivíduos dependentes e não submissos (Han, 2018, p. 29-30). A partir do psicopoder o indivíduo não impõe silencio à psique, mas ao contrário comunica, fala dos seus ideais, compartilha seus desejos, preferências, necessidades e sonhos, por fim torna-se um sujeito interativo, livre, onde a força de produção é a psique e o trabalhador torna-se ao mesmo tempo empregador-empregado.

0 biopoder vem tratar do poder sobre o corpo social, onde o conhecimento de poder utiliza as estratégias de tecnologia política ou biopolítica para converter o corpo em instrumento de produção. Enquanto que o psicopoder utiliza a psicopolítica proposta utilizada por Han (Esposito, 2012; Han, 2016).

O termo ecopoder para Leff (2014) pode ser analisado a partir de três perspectivas da epistemologia, economia e política. Para a compreensão do ecopoder, Leff (2014) faz o chamamento para a racionalidade ambiental compreendida como a natureza e o ser humano, ambos sendo vítimas das estratégias técnico-científicas e jurídico-econômicas que justificam a presença da natureza por meio da racionalidade teórico-instrumental. A globalização ele chamou de domínio técnico-econômico que de toda forma acelerou a morte do planeta (Leff, 2014, p. 12).

Para Foucault (2016), existe um poder sobre a vida de forma que as novas tecnologias de governo tem como objetivo transformar o poder soberano de vida ou morte em "um poder que é positivamente exercido na vida, que tenta administrar, aumentar, multiplicar, exercer controles e regulamentos precisos sobre a vida em geral", onde a base de poder do biopoder concentra-se em um elemento indispensável no desenvolvimento do capitalismo, a produção corporal e os processos biológico-econômicos (Foucault, 1977, p. 168-169). Dessa forma, o trabalho tido como capital por excelência determina o sentido produtivo da sociedade, faz dela o DNA produtivo que resulta na autorrealização e socialização da pessoa que trabalha (Güttrón Torres, 2019).

E, nesse sistema econômico imbuído da transparência, a sociedade é libertada da competição e agressividade, dessa forma saindo de uma sociedade deprimida para, segundo Foucault, sujeitos com domínio da psique individual e imaginários sociais. Essa seria a ideal relação de poder que se desejaria entre a comunidade do entorno e a gestão dos empreendimentos do aterro sanitário SMOC e da usina de biogás GNR Fortaleza. A população do entorno percebida como seres humanos com direito aos recursos naturais (Ortiz de Landázuri, 2017).

Para Leff (2009) e Naredo (2007) a estrutura do ecopoder baseia-se na crise ecológica distribuída em três áreas, a epistemológica, a econômica e ético-política. Na área epistemológica há a predominância de anti-natureza, a irracionalidade tornou-se razão (Marcuse, 2003), o não a verdade, mas o político direito, ainda, o efeito é analisado, mas não a causa, a exemplo do aquecimento global que é um efeito e não a causa do problema 
ecológico, no setor da saúde a pílula para dormir é prescrita soluções fáceis e final feliz, a linguagem da pós-verdade há um vazio de significados e as decisões são feitas com base em negócios e poder político, dentre outros. Na área da economia, percebe-se a exploração desequilibrada de recursos naturais, onde o mais importante é manter o modelo econômico citado pelo país com base no crescimento ilimitado. A crescente produção de resíduos sólidos promove a indústria dos veículos para fazer o transporte e promover 0 desenvolvimento local e regional, não se dando conta do desperdício por não reciclar, reutilizar e realizar a coleta seletiva dos referidos resíduos. Há uma grande ascensão da economia especulativa. Banqueiros e outros com posse do dinheiro de terceiros fazem girar as negociações, interesses pessoais esmagam os mais vulneráveis, os pobres, enfim, o capitalismo hegemônico explora, desregula, privatiza em nome da liberdade. Na dimensão ético-política, percebe-se uma negação da existência dos problemas ambientais, vive-se um faz de conta do controle da ética e da política somente por razões econômicas e pelo crescimento da produção infinita. A desigualdade social impera implacável e acelerada. 0 medo assola a sociedade como forma de opressão e submissão. Portanto, instala-se na crise humana um ecocídio, ou seja, situação de perigo à vida e a vida humana. Percebe-se que a relação injusta de poder-conhecimento resulta em insustentabilidade política, socioeconômica, cultural, ética, técnico-científica e ambiental. Afinal, o limite não se opõe à liberdade, mas uma condição para o respeito e a existência da alteridade. Viu-se muito presente essa realidade de desigualdade social estampada na vida da população do entorno a exemplo de até mesmo o direito ir e vir sendo negado.

A crise ambiental vivida pela humanidade reflete as ações de biopoder, ou seja, a pessoa está fora da natureza, como bem explica Capra (1999). Para Capra (1999), o fato do homem se projetar ou se ver quase sempre acima ou fora da natureza como fonte de todos os valores numa perspectiva separacionista quer de outros grupos, quer de gênero, sempre fortalecendo privilégios de poucos em detrimento de muitos, alimentada pela visão ideológica de crescimento e de progresso presente na Revolução Industrial e movida pela capacidade de consumo de bens e serviços, numa velocidade maior do que o planeta consegue repor, deu lugar a uma crise socioambiental que a Ecologia Rasa vem dialogar, aprofundar como forma de apresentar a verdadeira história e necessidade do homem perceber que tudo leva a interdependência na relação do ser humano com a natureza e que o homem é apenas um dos elementos que compõe a colcha de retalho que é a vida no planeta, ou seja, cada fio, cada pedaço de pano importa significativamente, deve ter seu espaço em busca de formar o que Capra chama de teia da vida. Ainda, de modo que é preciso frear a exaustão da terra diante da perda da biodiversidade, da qualidade e quantidade de água doce e das mudanças climáticas, a queima de combustíveis fósseis por energia e transporte, plástico, metais, concreto e metais invadiram terra e mar nesta nova era geológica chamada Antropoceno, ou seja, "Era da Humanidade" onde o homem exerce grande influência com suas ações. Portanto, é paradoxal essa relação de poder do homem na perspectiva socioambiental: a promessa de conforto e de viver bem pelo consumo de bens e serviços na vida de poucos e a existência da miséria e a pobreza na vida de muitos. Essa situação evidenciada por Fritjof Capra pode estar infiltrada na realidade de vida da população do entorno que experimenta diariamente a miséria em detrimento a tanto lucro obtido pelos gestores da usina e do aterro sanitário (Capra, 1999).

A Ecologia Política vem trazer uma perspectiva de como se dá a relação de poder entre atores sociais e a natureza, portanto, se faz necessário, inicialmente, compreender o objeto de estudo da Ecologia Política. Desse modo, destaca Martinez-Alier (2011) que a

Ecologia Política estuda os conflitos locais e internacionais pela extração de recursos e evacuação de resíduos, e analisa as lutas de poder para determinar os procedimentos de decisão nas avaliações ambientais segundo se permitam ou se proíbam certas linguagens de valorização" (Martinez-Alier, 2011, p. 47). 
Vale destacar quea Ecologia é uma ciência que estuda a relação triangular entre indivíduos de uma espécie, sua atividade e seu meio ambiente, assim como ao mesmo tempo a condição e o produto da atividade desta mesma espécie, ou seja, a condição de vida da referida espécie (Lipietz, 2003).

Portanto, é a partir das relações dos atores sociais com a natureza que pode ser percebida a relação de poder existente nesses meios, tendo em vista seus interesses coletivos e individuas de apropriação dos recursos naturais estudados e identificados por meio da Ecologia Política.

Nesse sentido, também se faz necessário entender o que é e como acontecem as relações de poder entre os diversos atores sociais e o uso dos recursos naturais. $\mathrm{Na}$ perspectiva de alguns estudiosos, a exemplo de Foucault (2018) e Gumbowsky et al. (2019), o poder é inerente à condição humana, assim sendo, sua existência se justifica pela relação entre indivíduos ou nas relações sociais e seus interesses. Ainda segundo Foucault (2018): “[...] rigorosamente falando, o poder não existe; existem práticas ou relações de poder. 0 que significa dizer que o poder é algo que se exerce, que se efetua, que funciona". Percebeu-se que na relação de poder entre a comunidade do entorno e os atores sociais dos empreendimentos do ASMOC e da usina, os interesses são bastantes diferentes, de forma que os proprietários colocam o lucro acima de tudo, enquanto que a população do entorno ainda vivem na invisibilidade, tentando um meio para sobreviver (Foucault, 2018, p. 17).

Como bem lembraram Gumbowsky et al. (2019), para Foucault (2018) “[ ...] o que faz com que o poder se mantenha e que seja aceito é simplesmente que ele não pesa só como uma força que diz não, mas que de fato ele permeia, produz coisas, induz ao prazer, forma saber, produz discurso". Essa realidade é pertinente a situação vivida pelos atores sociais da gestão do aterro e da usina, tendo em vista nos seus discursos afirmarem que essa comunidade do entorno é assistida com cestas básicas, atividades do viveiro, embora não é o que se presencia na vida dessa população (Foucault, 2018, p. 45).

Ainda de acordo com Gumbowsky et al. (2019), o poder é inerente aos seres humanos, a constituição das relações de poder tem como protagonistas os indivíduos e, assim sendo, o poder passa a ser o resultado de ações produtoras de poder.

Em Gumbowsky et al. (2019), a dinâmica do poder se constitui a partir da fiscalização e controle da vida coletiva e privada, tendo como fonte a rede de relações sociais, de jogo de poder e de interesses que formam a sociedade e que para Foucault (2015), “[ ...] é quase um controle direto ou indireto da existência” (Foucault, 2015, p. 194). Para isso faz sentido observar o cumprimento de regras sociais no mercado de trabalho, nas instituições de ensino, na cobrança de tributos, controle dos recursos naturais, dentre outros. Dessa forma, sabe-se que há um sistemático controle econômico, ambiental, cultural e político da sociedade e da natureza, ou seja, quase sempre o poder exerce sua força sobre as ações humanas ou sobre si mesmo.

No Brasil, a legitimação do poder é notável desde o Brasil Colônia quando das formas e os mecanismos de vigilância e controle por parte das relações de poder presente nas ações do Estado Lusitano por meio da vigilância e do controle sobre diversos setores da sociedade colonial brasileira, a exemplo da vida dos colonizados com o objetivo de monitorá-los e explorá-los com a cobrança de impostos. De modo que esse tipo de gestão ficou conhecida pela literatura brasileira como caracterização típica pela manipulação e exploração humana, econômica e socioambiental pela Metrópole portuguesa com o apoio das oligarquias locais. Dessa forma, Portugal na condição de Metrópole e munido de apoio do poder das elites locais exerceu um efetivo poder soberano sobre os nativos com a imposição de práticas econômicas, culturais e sociais à colônia (Gumbowsky et al., 2019). 0 processo de colonização, por ser um acontecimento histórico, usou do poder enquanto relação predatória de conhecimentos tradicionais, de saberes ambientais que aos poucos 
foram sendo apagados, por uma lógica extrativista. Esse poder colonial instaurou o ecocídio, a morte de espécies e de conhecimentos (Santos, 2000).

Nesse contexto, de fato a situação vivida pela comunidade do entorno se imprime um retrato do Brasil colonial, até mesmo no índice de analfabetismo, inclusive $o$ analfabetismo funcional. Essa situação de analfabetismo está presente no Relatório de Impacto Ambiental (RIMA) do aterro sanitário onde afirma existir uma maioria de analfabetos naquele entorno, e, embora passados mais oito anos da instalação do ASMOC II e 23 anos do ASMOC I, essa população não incluída em programas de alfabetização, ou seja, impactando de forma negativa na vida dessa comunidade (Santos, 2000; Ecofor, 2011, p. 67-69).

Com o intuito de compreender a relação de poder no controle ambiental do país atrelado ao desenvolvimento econômico, cita-se a Política Nacional de Meio Ambiente (PNMA) (Brasil, 1981), o Conselho Nacional do Meio Ambiente (CONAMA) (Brasil, 1981) e suas resoluções, a exemplo da Resolução CONAMA no 357/2005 (Brasil, 2005), da Resolução CONAMA no 404/2008 (Brasil, 2008), da Resolução CONAMA no 001/1986 (Brasil, 1986), da Política Nacional dos Resíduos Sólidos (PNRS) (Brasil, 2010), da Política Nacional de Educação Ambiental (PNEA) (Brasil, 1999), do Sistema Nacional do Meio Ambiente (SISNAMA) (Brasil, 1981), dentre outras que apresentam diretrizes, objetivos e metas para ordenar juridicamente a política de meio ambiente no Brasil. A partir de cada segmento e de cada política de meio ambiente norteia-se as relações de poder que existem entre si. Por exemplo, o poder do Estado que não consegue cumprir com os prazos acordados com a política Nacional dos Resíduos Sólidos no que se refere à erradicação dos lixões definindo prazo para o ano de 2014 e posteriormente para 2018 e a instalação de aterro sanitários que ainda é tão insuficiente. Situação tão aparente na realidade da gestão dos resíduos sólidos que chagam ao aterro sanitário sem a devida separação na fonte geradora, ou seja, descumprindo a PNRS.

No Brasil, ainda perpassa na mentalidade de muitas pessoas que os recursos naturais são infinitos, de uso gratuito e, assim sendo, pode ser usado como quer, do jeito que quer e sem a preocupação de conservar, preservar e cuidar. E, é nesse pensamento que a problemática ou crise ambiental vai se instalando com força nas relações sociais e de poder gerando conflitos colocando em risco a sobrevivência de quem mais precisa e das gerações futuras (Naves, 2004).

Para Naves (2004), mesmo que o meio ambiente seja tido como algo socialmente construído, na realidade esse entendimento nem sempre é reconhecido pelas pessoas. Com isso, afirma Bourdieu (2002, p. 118), o "mundo social é também representação e vontade, e existir socialmente é também ser percebido como distinto". Para melhor compreender a realidade, parte-se do princípio de que esta é uma representação que depende do conhecimento e do (re)conhecimento. Nesse sentido, nessa mesma perspectiva de diferenciação entre natureza e indivíduos, é usada para distinguir alguns grupos humanos (com menor poder e outros com maior poder).

\section{Procedimentos metodológicos}

Para a realização deste estudo, baseou-se em revisão de literatura e análise documental, utilização da técnica da "Bola de neve", realização de trabalho de campo e 10 entrevistas in loco e aplicação de 14 questionários com os atores sociais investigados.

Para averiguar a relação de poder na determinação do acesso e uso dos recursos naturais entre os atores sociais do entorno, funcionários do ASMOC e gestores da usina de biogás GNR através da Ecologia Política, inicialmente, recorreu-se à revisão de literatura com base na temática em discussão, à luz dos estudos, pesquisas e contribuições dos principais aportes teóricos de Porto (2007), Alier (2011), Foucault (2012), Leff (2014), 
Ortiz de Landázuri (2017), Gumbowsky et al. (2019) e Güttrón (2019), que guiaram o desenvolvimento deste estudo.

Também foi utilizada a técnica da "Bola de Neve" (Biernack e Waldorf, 1981), que consiste em, a partir da entrevista realizada com atores-chaves, a indicação e identificação de outros importantes atores sociais. Assim sendo, foi realizada 10 entrevistas, as visitas in loco e aplicação de 14 questionários semiestruturados aos atores sociais que puderam contribuir para compreender a relação de poder existente entre os atores sociais envolvidos na pesquisa.

Vale ressaltar que, anteriormente ao início do processo de aplicação de questionários e realização das entrevistas, fez-se uso do termo de Consentimento Livre Esclarecido e da Carta de Anuência, que são instrumentos que asseguram a redução de riscos aos atores sociais pesquisados, por meio de autorização por escrito, assim como, para a identificação desses sujeitos envolvidos nesta pesquisa, optou-se por usar nomes fictícios. A referida pesquisa foi aprovada pelo Comitê de ética da Universidade Federal da Paraíba (UFPB/CCS), por meio do site da Plataforma Brasil para obtenção da análise e aprovação por meio do Parecer no 4.575.625 e CAAE 4248921.4.0000.8069.

\section{Caracterização da área de estudo}

O Aterro Sanitário Metropolitano Oeste de Caucaia (ASMOC), com área de123 ha, localiza-se no Município de Caucaia, Região Metropolitana de Fortaleza, Estado do Ceará. 0 acesso ao aterro sanitário é realizado por meio da rodovia BR-020, na altura do km 15 por um percurso de 1,6 km em asfalto, construído a partir da margem sul desta rodovia (Carvalho, 2016). 0 mapa de localização da área de estudo está apresentado na Figura 1.

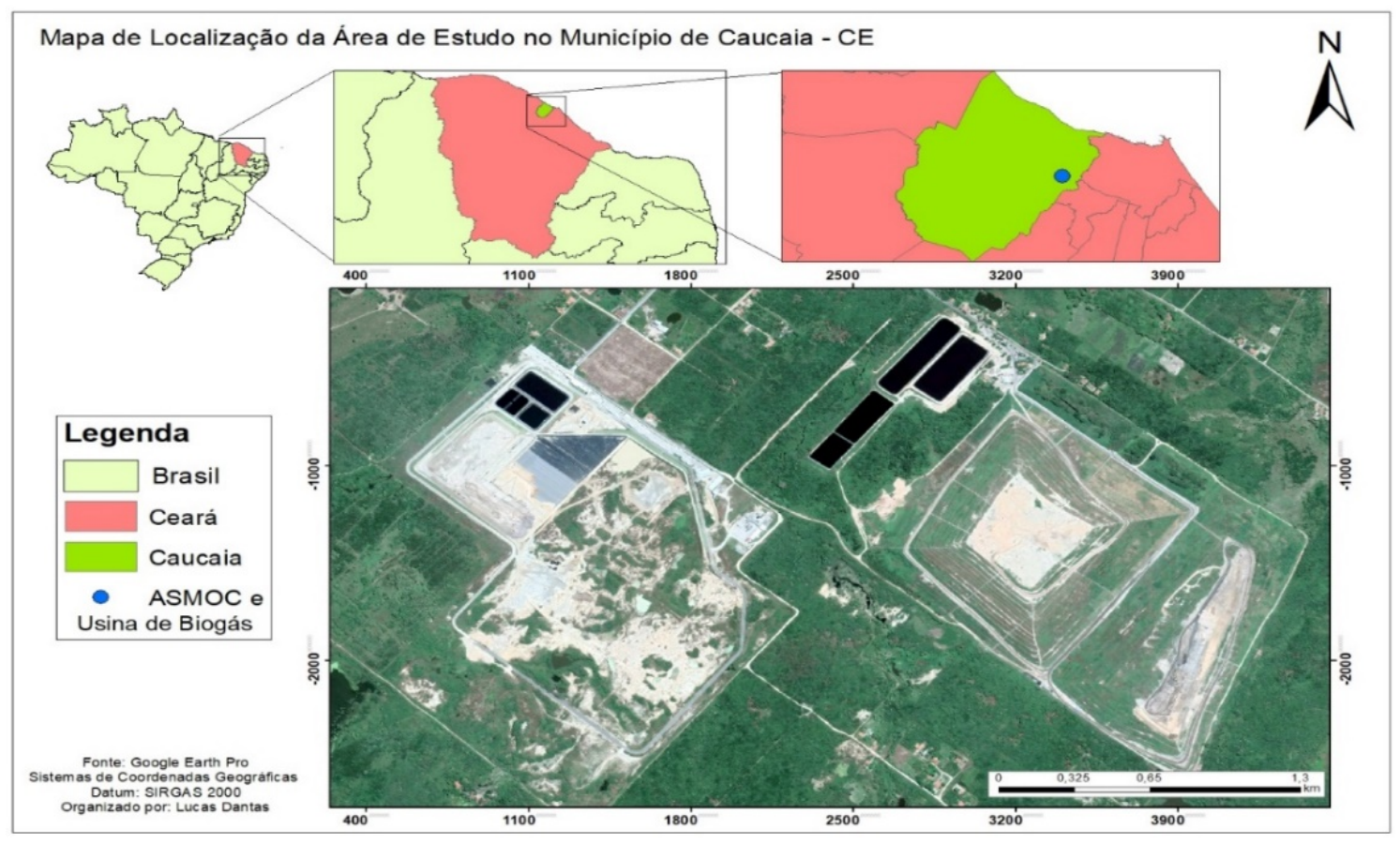

Figura 1. Localização do Município de Caucaia no Estado do Ceará. Aterro Sanitário ASMOC e a Usina de biogás GNR Fortaleza CE. Elaboração: Lucas Dantas, 2020.

O Município de Caucaia está localizado na porção nordeste do Estado do Ceará, cujo centro geográfico tem as coordenadas $3^{\circ} 44^{\prime} 4^{\prime \prime}$ de Latitude Sul e $38^{\circ} 39^{\prime} 23^{\prime \prime}$ de Longitude Oeste. 0 município limita-se ao Norte com o Oceano Atlântico; ao Sul com o 
Município de Maranguape; a Leste com os Municípios de Maracanaú, Fortaleza e Maranguape; e a Oeste com os Municípios de São Gonçalo do Amarante e Pentecoste (PDDU/CAUCAIA, 2021).

Para operacionalizar o aterro sanitário ASMOC conta-se com a Ecofor Ambiental S/A, do Grupo Marquise. A Empresa Municipal de Limpeza e Urbanização (EMLURB) e a Autarquia de Regulação, Fiscalização e Controle dos Serviços Públicos de Saneamento Ambiental (ACFOR) são responsáveis pela vistoria do Grupo Marquise (PMGIRS) (Fortaleza, 2012; Carvalho, 2016).

Os Municípios de Fortaleza e Caucaia descartam seus resíduos sólidos no Aterro Sanitário ASMOC, os quais são oriundos da varrição, capinação, coleta urbana domiciliar e comercial, dentre outros. O Município de Fortaleza por não dispor de terreno com área equivalente para a instalação de aterro sanitário necessitou fazer um acordo com o Município de Caucaia para a instalação do ASMOC em Caucaia. O planejamento inicial foi para que o aterro tivesse uma vida útil de 20 anos, embora, pelo fato desses municípios não realizarem a coleta seletiva esse tempo foi reduzido para 16 anos, ou seja, quatro anos a menos (Fortaleza, 2012).

Assim sendo, em 2014, o ASMOC com sua vida útil prestes a encerrar, foi realizada a compra de um terreno com área de 23 hectares ao lado do ASMOC para a instalação de um novo aterro sanitário. Tendo em vista o grande volume de emissão de gases de efeito estufa, a exemplo de metano e dióxido de carbono, foi instalada uma usina de biogás com o objetivo de mitigar as emissões desses gases e produzir biometano. A Figura 2 apresenta a usina de biogás GNR, o aterro sanitário ASMOC e seu entorno (Fortaleza,2012; SEMACE, 2019).

Figura 2. Localização do novo aterro sanitário do ASMOC e da usina de biogás GNR Fortaleza.

\section{Resultados e discussão}

Identificação dos atores sociais da comunidade do entorno da usina e aterro

Para melhor compreender quem são os atores sociais envolvidos nesta pesquisa, apresenta-se alguns deles na Tabela 1. 
Tabela 1. Descrição dos atores sociais envolvidos na pesquisa.

\begin{tabular}{|c|c|}
\hline Ator social & Participação \\
\hline Sales (C.A.S.) & $\begin{array}{l}\text { Membro da comunidade do entorno do aterro sanitário ASMOC que } \\
\text { reside há mais de } 50 \text { anos no local. A senhora Carolina Sales nasceu e se } \\
\text { criou no local onde foi instado o aterro sanitário. Hoje mora a menos de } \\
10 \text { da entrada do aterro. Vive em condições precárias. Falta-lhe tudo, } \\
\text { inclusive a saúde. }\end{array}$ \\
\hline Sousa (L.P.S.) & $\begin{array}{l}\text { Residente em frente ao novo aterro sanitário e a usina de biogás GNR. } 0 \\
\text { local é de muita poluição sonora. O barulho dos veículos causado pelo } \\
\text { grande fluxo de caçambas e carros compactadores que transportam os } \\
\text { resíduos sólidos urbanos e domiciliares até ao aterro acontece durante } \\
24 \text { horas. Sr. Sousa tem dificuldade de ouvir tento em vista à poluição } \\
\text { sonora. Ele é proprietário de um comércio de diversos gêneros } \\
\text { alimentícios (mercearia) onde abastece a população do entorno. O } \\
\text { mesmo reside há mais de } 30 \text { anos neste local. }\end{array}$ \\
\hline Vieira (G.P.V.) & $\begin{array}{l}\text { Residente há mais de } 10 \text { anos no local, vive com pequeno salário em } \\
\text { construção civil no entorno do aterro sanitário. Tem Ensino Fundamental } \\
\text { incompleto. Em época de inverno fica sem trabalho, porque as vias } \\
\text { terrestres ficam intransitáveis. }\end{array}$ \\
\hline Silvestre (M.R.S.) & $\begin{array}{l}\text { O Sr. Mário Silvestre, mora há mais de } 22 \text { anos no local. Tem uma } \\
\text { marmitaria que fornece almoço para os trabalhadores do aterro e da } \\
\text { usina. Seu pequeno comércio ajuda a sustentar sua família. O seu nível de } \\
\text { escolaridade é o Ensino Fundamental incompleto. O mal cheiro de o } \\
\text { chorume dar dor de cabeça e isso dificulta a saúde da família. }\end{array}$ \\
\hline Barbosa(M.C.B.) & $\begin{array}{l}\text { Barbosa é engenheira da Usina de biogás. Não reside na cidade onde } \\
\text { trabalha. }\end{array}$ \\
\hline Medeiros (P.C.M.) & $\begin{array}{l}\text { Medeiros faz parte da diretoria especial de resíduos sólidos. Não reside } \\
\text { no município dos equipamentos em discussão. }\end{array}$ \\
\hline 99Nunes(P.V.N.) & $\begin{array}{l}\text { Nunes faz parte da diretoria da usina de biogás GNR. Não reside no } \\
\text { município onde está instalada a usina de biogás GNR. }\end{array}$ \\
\hline Moreira(J.C.M.) & $\begin{array}{l}\text { Moreira faz parte da gerência do aterro sanitário. Não reside no } \\
\text { município onde é instalado o aterro sanitário ASMOC. }\end{array}$ \\
\hline
\end{tabular}

Diante do apresentado na Tabela 1, percebe-se que todos os atores sociais da comunidade em torno da usina e do aterro têm seu nível de escolaridade pautado no Ensino Fundamental incompleto. Enquanto os gerentes, diretores e engenheiros dos equipamentos não residem na cidade onde são instalados os equipamentos. É possível perceber como essa população vive à margem. Essa situação visível de poder tornou-se evidente ao entrevistar os seguintes atores sociais do entorno dos equipamentos, Mário Rodrigues Silvestre, Lucas Pereira Sousa, Geraldo Pereira Vieira e Carolina Alves Sales, observou-se também que a maioria dessa população do entorno vive de pequenos salários.

Diante das situações elencadas no decorrer dessa discussão,pode ser percebido na relação de poder existente no ato da concepção do direito de instalar o aterro sanitário ASMOC, segundo Carolina Sales (2020) proprietária de parte do terreno onde se instalou o ASMOC, é que se institui um imperativo social e econômico onde os proprietários são orientados a ceder o terreno e transferir suas moradias para outros locais. E, tendo como mais agravante nessa relação de poder a inexistência da participação da população do entorno nos lucros com a produção, ou seja, os recursos naturais tornando privado e a insuficiência de participação do coletivo. Um direito que aquela população do entorno do aterro não teve participação e que em Gumbowsky et al. (2019), Foucault se justifica como "[...] as leis sociais são feitas por pessoas às quais elas não se destinam, mas para serem aplicadas àqueles que não as fizeram" (Foucault, 2015, p. 22). 
Outra situação em que se sobrepõe a relação de poder é o produto biometano produzido pela usina de biogás GNR Fortaleza, advindo dos resíduos sólidos urbanos não chegar às residências do entorno, ou seja, mais uma vez um imperativo social se acentua na relação de poder de quem mais tem poder econômico sobre os mais pobres. A referida população compra gás de cozinha GLP (gás liquefeito de petróleo), um gás fóssil e por um valor muito caro, o que pode estar cada vez mais deixando a população vulnerável economicamente e socialmente e, dessa forma alimentando o capitalismo exacerbado. Essa mesma relação de poder imprime tratamento desigual no uso de um produto que existe a partir da coleta seletiva de resíduos sólidos urbanos e que se privatiza pelo poder político e econômico. Dessa forma, se contribui para manutenção do poder e suas estruturas.

Nessa perspectiva o filósofo francês Foucault desmascara o mito da "justiça do direito" de modo que os que detém o poder de fabricar e vender o produto do aterro ASMOC e da usina GNR usa do direito e da justiça estabelece na violência de quem impõe a lei e da população do entorno que obedece-a. É por este olhar que é possível perceber os inúmeros conflitos socioambientais e econômicos no dia a dia que são constitutivos do modelo sistêmico social adotado e da sua estrutura de relações de poder (Gumbowsky et al., 2019).

Nesse sentido, percebe-se que a insuficiência de conhecimento sobre a legislação ambiental brasileira, a exemplo da Política Nacional da Educação Ambiental, que embora sua vigência tenha mais de vinte anos, a comunidade do entorno desconhece a referida lei.Como fica evidente, tem-se uma política que tem como objetivo criar valores sociais, conhecimentos, habilidades, competências e atitudes voltadas para a sustentabilidade ambiental, social, econômica, cultural e política na perspectiva do envolvimento de toda sociedade tanto no aspecto do ensino formal quanto no não-formal. Duas décadas se passaram, assim sendo o que o Brasil tem de mensurar, perceber de prática dessa política? As escolas brasileiras o que têm feito na perspectiva da educação ambiental? A sociedade brasileira o que tem feito para a aplicabilidade desta tão importante política de educação ambiental?

A pandemia da COVID-19 tem revelado o quanto ainda o povo brasileiro está distante das ações da política de educação ambiental, ao mostrar nas mídias, redes sociais, TV, rádios, jornais as diversas regiões do Brasil que até água faltava para lavar as mãos, uma recomendação básica da Organização Mundial da Saúde. Nesse sentido qual a relação de poder do Estado, das entidades privadas e da população na implementação da política básica de educação ambiental? Esse tipo de comportamento imprime poder parecer descaso com a saúde pública e qualidade de vida socioambiental, assim como a insuficiência de fiscalização, monitoramento e avaliação das políticas públicas ambientais.

0 que se presencia no dia a dia de vários municípios brasileiros é a inobservância da lei descrita nos meios de comunicação. Os rios, lagos, lagoas sofrendo degradação ambiental, assoreamento, secando por falta de cuidados adequados, a exemplo de resíduos sólidos como plásticos, papeis, latas, garrafas pet, metal jogados no meio ambiente, causando inundação, contaminação, poluição, desperdício, dentre outros. Como se pode observar o curso de água sendo afetado com as ações do homem.

Neste estudo de pesquisa, a Lagoa João Batista fica a menos de 50 metros do aterro sanitário do ASMOC. Ou seja, uma água que era potável tornou-se imprópria para o consumo da população do entorno. Isso caracteriza uma relação de poder conflituosa entre a população e os proprietários do aterro e da usina de biogás. Assim como o descumprimento da Resolução do CONAMA nº 001/1986 (Brasil, 1986) no que refere à insuficiência de avaliação dos impactos ambientais e da Resolução do CONAMA no 357/2005 (Brasil, 2005) nos cuidados com a água. A Figura 3 apresenta a Lagoa João Batista. 


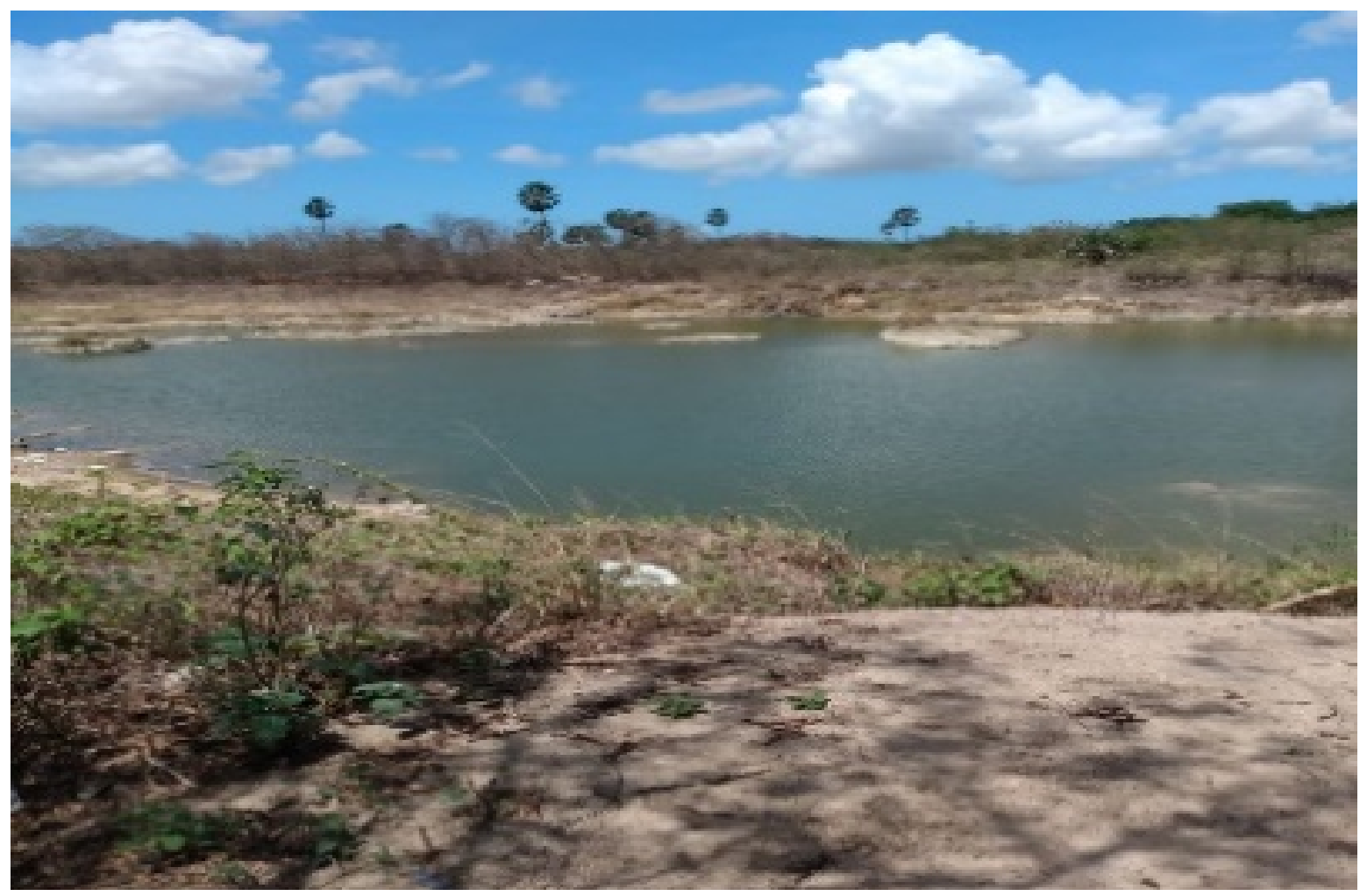

Figura 3. A Lagoa João Batista e o Aterro Sanitário ASMOC I.

A Lagoa João Batista que fica a um raio de apenas $104 \mathrm{~m}$ do aterro sanitário ASMOC I (Figura 3). A gerência do ASMOC afirma que não tinha conhecimento do ocorrido. Dessa forma, percebe-se o quanto a população do entorno é invisível.

Outra situação de conflituosa relação de poder é o fato de os resíduos sólidos urbanos chegarem ao aterro sanitário ASMOC sem a devida coleta seletiva gerando desperdício de materiais que poderiam ser utilizados na reciclagem evitando o uso de matéria prima e gerando emprego. Assim como desperdício econômico por não reciclar os referidos resíduos. A inexistência da coleta seletiva e de programa de educação ambiental de forma contínua e permanente terá impacto negativo por diminuir a vida útil do aterro sanitário e promover maior quantidade de geração de gás de efeito estufa. Assim sendo, percebe-se a insuficiência da relação de poder do governo no cumprimento das leis ambientais o que resulta também no aumento da desigualdade social. Ou seja, tanto descumpre a política nacional de educação ambiental , assim como a Resolução CONAMA no 404/2008 (Brasil, 2008), que dispõe em seu capitulo XV sobre programa de educação ambiental e coleta seletiva e comprometendo o desenvolvimento sustentável (Burnley, 2007; Brasil, 2008; Guerrero et al., 2013; Esmaeilian et al., 2018; Centrulo et al., 2020). Com a reciclagem reduz- se impactos ambientais, econômicos e sociais. Portanto, o ato da descontinuidade de práticas das políticas de educação ambiental é visível e requer análise da relação de poder (Gonçalves et al., 2019). A Figura 4 apresenta a forma como os resíduos sólidos chegam e são tratados no aterro sanitário ASMOC. 


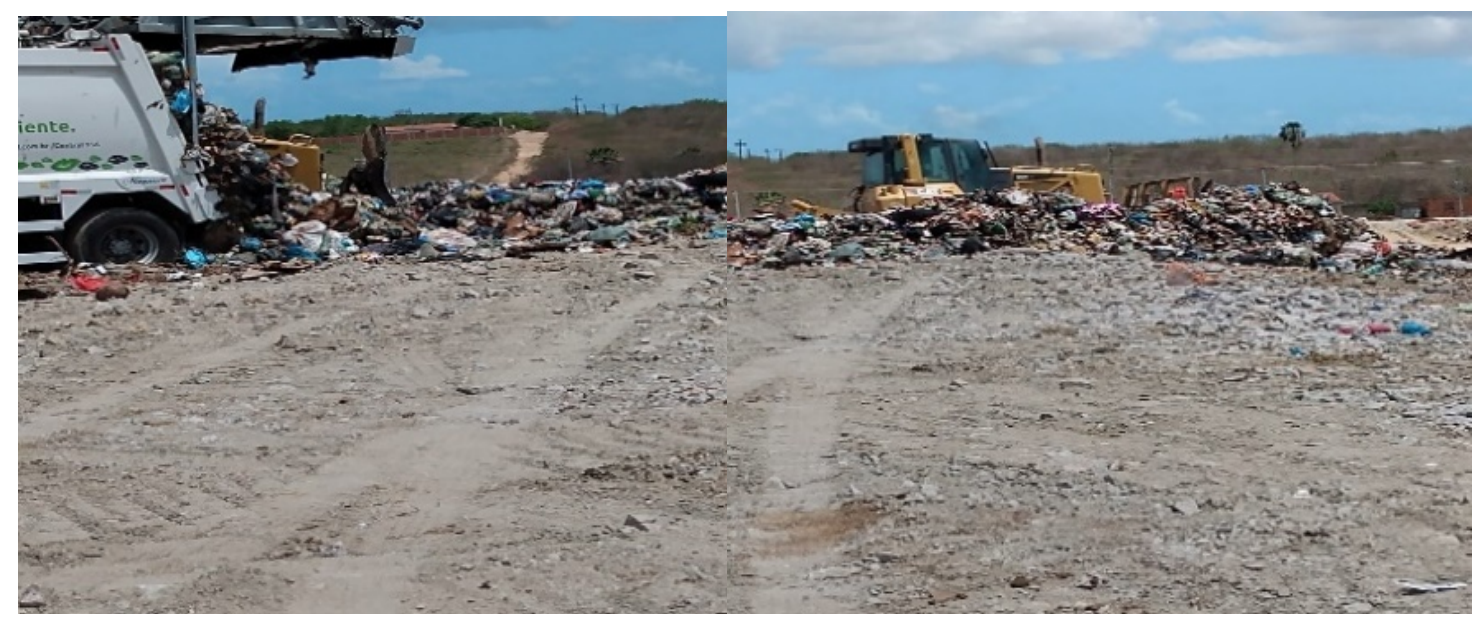

Figura 4. Resíduos sólidos misturados. Aterro Sanitário ASMOC.

Como se pode ver a sociedade está inserida integralmente em um campo político em que as relações de poder estão ligadas diretamente sobre a natureza e o ser humano. De modo que as referidas relações dirigem, permeiam instituições privadas e órgãos públicos, celebram acordos numa perspectiva procedimental e de relações com fins exclusivamente econômicos (Gumbowsky et al., 2019).

Nesse sentido é importante observar o quão está presente a relação de poder de forma desigual e injusta, onde uma só empresa privada consegue sozinha gerir os recursos coletivos de uma cidade. O Município de Fortaleza no Estado do Ceará conta com a empresa Ecofor Ambiental S/A do Grupo Marquise que realiza a operacionalização do Aterro Sanitário Metropolitano Oeste de Caucaia (ASMOC). A Ecofor é a concessionária responsável pela coleta sistemática ou coleta comum dos resíduos sólidos urbanos, transporte e destino final dos resíduos sólidos. A referida empresa detém por 20 anos a concessão com exclusividade dos serviços públicos de limpeza urbana, através da Concorrência Pública 001/2002, publicada em Diário Oficial de 30/01/2003, e Contrato firmado em 06/05/2003, no valor de $\mathrm{R} \$ 1,718$ bilhões com reajuste anual de acordo com o Índice Nacional de Preços ao Consumidor (INPC)/IBGE e o Plano Municipal de Gestão Integrada de Resíduos Sólidos (PMGIRS) (Fortaleza, 2012, p. 36; Carvalho, 2016). 0 que se imprime desta realidade de gestão dos resíduos sólidos é que a população do entorno tem participação insuficiente na operacionalização do aterro. 0 que se vê é uma comunidade cada vez mais desassistida dos seus direitos, a exemplo de vias não pavimentadas para se locomover, a não geração de emprego compatível com a sua realidade, condições insalubres de sobrevivência água de lagoas e riachos contaminados a exemplo do Riacho Garoto e diversos outros conflitos socioambientais e econômicos. Dessa forma, quem é pobre torna-se cada vez mais pobre e quem é rico cada vez mais rico. E, desse modo vai crescendo o número dos desiguais no Brasil.

A diferença na relação de poder entre a gestão dos resíduos sólidos dos dois municípios brasileiros leva a vários questionamentos na perspectiva econômica, social, cultural, política e ambiental. 0 município de Fortaleza não tem institucionalizada a coleta seletiva nem programa de educação ambiental de forma contínuo, assim como é insuficiente a inclusão dos catadores de resíduos sólidos e, dessa forma descumpre a Política Nacional de Resíduos Sólidos e outras legislações ambientais.

Percebe-se diante desse estudo em discussão, o tema centralização de poder nas mãos de poucos, lucratividade por meio de um grupo elitizado, crescimento e desenvolvimento econômico e poder político está no topo do degrau da sociedade capitalista, enquanto que os mais pobres, o trabalhador, esses estão na parte inferior da 
pirâmide social. Com isso os mais desiguais sempre mais vulneráveis e sem vez e voz. Nem sequer têm direito a questionar seus direitos, na maioria das vezes perdem estes e fica por isso mesmo. Nesse percurso continuam sendo escravizados de um direito ambiental garantido por leis, mas que fica só na lei, no papel e que muitas vezes até sabem sobre seus direitos, mas no momento de buscar estes as portas se fecham, outras vezes são vencidos pelo cansaço. Portanto continuam vivendo à margem do desemprego, da sobrevivência, do risco socioambiental, econômico e político. Para Foucault "[...] existe um sistema de relações de poder que limita, proíbe, invalida a constituição e a proliferação desse discurso e desse saber. Poder que penetra muito profundamente, muito sutilmente em toda a trama da sociedade" (Foucault, 2018, p. 131).

Nesse sentido, na tentativa de dar visibilidade aos mais pobres, os que fazem a comunidade do entorno e da usina GNR Fortaleza e do aterro ASMOC, faz-se necessário recorrer à Sociologia das Ausências que faz a relação com a Ecologia Política por meio da visibilidade dada ao diálogo que antes não existia, ou seja, o presente vivido pelos atores sociais tornam-se descobertos, visíveis, possíveis, de forma que os conflitos socioambientais denunciados pela Ecologia Política tornam -se agora visíveis à luz da Sociologia das Ausências de maneira a fortalecer esses vínculos da existência da realidade em discussão (Santos, 2000).

Na tentativa de definir o meio ambiente, Vincent (1995) diz que meio ambiente é um sistema que compõe todas as coisas vivas, assim sendo, a espécie humana é a parte que tem uma estrutura altamente complexa e diversificada que não pode se separar dos demais seres vivos. De acordo com Vincent (1995) "grande parte do nosso ambiente e da natureza (inclusive a natureza humana) tem uma relação causal com a pobreza, a doença, o trabalho alienante e, simplesmente, a necessidade de sobreviver em um sistema opressivo", Foucault (2018). Diante do citado por Vincent (1995), percebe-se na relação de poder entre os gestores do aterro sanitário ASMOC, da usina de biogás GNR Fortaleza e a população do entorno tem essa situação e é visível à maioria da população do entorno vivenciar a situação pobreza. Quantas famílias vivem em situação de pobreza a exemplo da família da Dona Carolina e outras que vivem numa pobreza, saúde precária e trabalho opressivo. 0 direito de vez e voz são negados, a situação de pobreza se instala sem pedir licença, a necessidade de sobrevivência fala por si só. Para manter o emprego e sobreviver, sofrem calados. Portanto, a situação descrita por Vincent (1995) é tão atual e presente em 2021 e está tão real o fato de que os laços entre a natureza humana e os recursos naturais estão intimamente ligados, possuem estreitos laços e dependência.

Neste sentido, torna-se evidente que o sistema capitalista envolve não só as relações econômicas e de mercado, mas relações socioambientais, culturais e de comportamentos com vistas ao uso dos recursos naturais. Segundo Santos (1999), a logística da modernidade capitalista se insta em um pensamento de uma natureza dissociada do dinamismo vivo, mas que tem forma inerte, infinita. Dessa forma, o trabalho humano explora os recursos naturais e se mantém às custas da natureza. A exemplo do que se presencia com os impactos socioambientais com a instalação da usina e do aterro sanitário, onde a água da Lagoa João Batista e a água do Riacho Garoto tornaram-se imprópria para o uso humano, assim como as vias terrestres por onde trafegam os caminhões para o transporte dos resíduos sólidos sofrem degradação e emitem dióxido de carbono com a queima de combustíveis fósseis. 0 ideal seria que os caminhões fizessem uso do biometano gerado por meio do biogás dos resíduos sólidos do aterro sanitário. Como isso não acontece, torna-se visível a exploração gananciosa do homem sobre os recursos naturais. Portanto, para Santos (2000), nessa relação de poder o homem se sobrepõe sobre a natureza, explora-a severamente, ou seja, o capital explora o trabalho e consequentemente explora a natureza. Com isso, percebe-se a necessidade de uma reflexão na mudança da relação de poder entre a humanidade e a natureza na busca pelo viés da sustentabilidade das gerações presentes e do futuro, de modo que a natureza

Rev. Bras. Gest. Amb. Sustent., 2021, vol. 8, n. 20, p. 1665-1685. 
suporte a carga da sobrevivência humana, afinal, a interdependência perpassa por todas as instâncias da vida, fazem parte de um meio sistêmico e interligado direta ou indiretamente. Para isto, basta observar a interferência no meio ambiente como um todo diante das mudanças climáticas que estão acontecendo. A exemplo das mudanças de temperatura e clima, derretimento das geleiras, inundações, secas mais prolongadas, escassez de água onde outrora chovia, desigualdade social, dentre outras. As mudanças climáticas são alterações no estado do clima da Terra que persistem por um longo período de tempo e que pode ter origem natural ou antrópica.

A natureza tem seus recursos pautados no uso coletivo. Embora, a relação de poder social e econômico com vistas ao modelo econômico capitalista que é utilizado pelo sistema econômico do Brasil e da América latina traga de forma visível a exclusão social e a crescente desigualdade social, e, com isso resultando em um país onde o número dos mais vulneráveis cresce cada vez mais. Essa relação está na apropriação dos bens de forma injusta, gananciosa e desumana. Dessa forma, atender aos Objetivos de Desenvolvimento Sustentável (ODS) é um desafio enorme para o Brasil em especial no que se refere a Erradicar a pobreza e a fome de todas as maneiras e garantir a dignidade e a igualdade, onde os mais vulneráveis não têm voz e nem vez, ou seja, são engolidos pelos que detém o poder.Assim sendo, percebe-se que com avaliação e monitoramento eficiente do uso dos recursos naturais e da efetividade das políticas públicas socioambientais são alguns dos diversos caminhos para alcançar os objetivos e metas traçados pelos ODS. É necessário fazer chegar ao Ensino formal e não-formal o conhecimento das políticas públicas de educação ambiental e suas respectivas práticas.

Nesse contexto, evidencia-se diante do citado, tem-se a marca da era geológica do Antropoceno, ou seja, "Era da Humanidade", onde as ações do homem deixam marcas de muitos desequilíbrios do planeta terra, dentre outros (Capra, 1999). Assim sendo, diante dessas inquietações, no dia 26 de janeiro de 2021, em entrevista ao ambientalista Capra (2021) perguntei sobre a problemática ambiental no Brasil e o que falta de fato para efetivar a legislação ambiental tornar-se prática no dia a dia das escolas de ensino formal no Brasil. Fritjof Capra respondera que:

"A Ecologia é multidisciplinar e é a ciência das relações entre os seres vivos e uma comunidade, entre eles e os ecossistemas. Então, a educação ambiental envolve as questões de Biologia, Física, Química, Ciência Política, etc. Nosso sistema escolar é muito fragmentado e separado em várias disciplinas. É difícil introduzir um programa multidisciplinar. Essa é a principal razão porque eu, Fitjof Capra e Pier Luigi Luisi escrevemos o livro titulado "A Visão Sistêmica da Vida”. No Brasil tem a teoria pedagógica de Paulo Freire que pode ser construída essa visão multidisciplinar e ecológica com base em Paulo Freire" (Capra, 2021).

Diante do exposto, percebe-se que vivemos em um mundo sistêmico, e, portanto, a humanidade necessita viver de forma sistêmica, ou seja, as ações humanas poderiam se aliar aos demais meios como físico e biótico, de forma a promover ações sustentáveis de maneira formal e não-formal.

Pensando sobre a racionalidade das coisas, dos fatos, da existência humana, da natureza ou dos recursos naturais, Ojaide (2013), traz uma série de comparações com o intuito de fazer repensar que para agir racionalmente basta ser um ser humano para conhecer a situação dos outros. Nesta perspectiva diz que o homem não precisa ser deficiente para sofrer a dor dos deficientes, não precisa ser minoria para entender o domínio do grande e assim sucessivamente. Assim sendo, de acordo com M. Weber (Mitzman, 1976), na tradição latino-americana, com base em sua herança judaico-cristão e ético-humanista, o ser humano é identificado como uma pessoa digna de resgate e redenção, portanto, a responsabilidade para o outro e para nós, deve ser ascendente e 
constante e de forma meramente humana. Na relação humana é preciso haver a paz, e esta paz significa viver com a verdade e, assim fazer uso da justiça social contra um sistema que se remete a aparências e interesses. Na visão de Mitzman (1976), os poderes invisíveis escravizam e alienam consciências de forma a produzir exclusão social, negando a dignidade, essa situação é bem própria na relação de poder dos gestores do aterro sanitário e da usina com a população do entorno. Onde os referidos gestores tornam-se cada vez mais ricos, a ponto de negar a história, esconder o rosto daquela gente que outrora era proprietária das terras hoje ocupadas pelos dois equipamentos em discussão, ou seja, os mais vulneráveis tornam-se invisíveis e até indignos de existir, sobreviver. Transitar nas vielas sem pavimentação torna-se, na maioria das vezes, impossível de ir e vir, em especial no período de inverno ficam ilhados.

A população do entorno do aterro sanitário e da usina de biogás são sinalizadas como utilizadas ao poder existente no biopoder por meio da biopolítica, tendo em vista viverem na submissão de um sistema operacional onde são invisíveis aos que detém o poder econômico e político, os gestores de ambos os equipamentos em discussão neste estudo. Antes da instalação e operacionalização dos referidos equipamentos essa população do entorno utilizava-se da teoria Han (2016) onde imprime o uso do psicopoder, tinham a liberdade de viver sem opressão. Utilizavam da terra seu sustento e sentiam-se livres. Assim deveria ser a relação entre a sociedade e a natureza. Isso corresponderia o equilíbrio ecossistêmico necessário para se promover a sustentabilidade socioambiental, econômica, política e cultural no planeta.

Nesse sentido, percebe-se que a população do entorno se instala numa invisibilidade tão bem definida no biopoder, elencado por Foucault (2018) e no ecopoder, evidenciado por Leff (2009) e Naredo (2007), quando da percepção no negacionismo da gestão do ASMOC e da Usina GNR, assim como da SEMACE, no que se refere ao cumprimento do documento (EIA/RIMA), que, mesmo depois de oito anos de existência, ainda não exigiu a execução das atividades da Fase 1 do ASMOC II, mesmo sabendo da obrigatoriedade de se cumprir no prazo máximo de um ano, ou seja, em 2012, onde mais de $\mathrm{R} \$ 2.000 .000,00$ (dois milhões de reais) que deveriam ser destinados à melhoria socioambiental não foram efetivados. Dessa forma, a degradação ambiental cada vez mais vai se instalando no local em estudo e se mantendo uma relação de poder fragilizada entre a população do entorno e os gestores do aterro sanitário e da usina GNR.

\section{Identificação dos atores sociais da comunidade do entorno da usina e aterro}

Na busca por identificar os principais atores, foi usada a técnica "Bola de Neve" (Biernack e Waldorf, 1981), que consiste em, a partir da entrevista realizada com atores-chaves, uns vão indicando outros atores que, de acordo com a sua percepção, fazem parte do processo e podem colaborar. Pode-se evidenciar o uso dessa técnica ao entrevistar o Sr. Lucas Pereira e Mário Rodrigues que indicaram a Sra. Carolina Alves para ser entrevistada, com base na afirmação por ser moradora do local onde está instalado o aterro sanitário ASMOC e, posteriormente, à implantação do aterro, passou a morar muito próximo ao aterro sanitário, ou seja, a menos de $50 \mathrm{~m}$, onde reside até os dias atuais.

Alguns atores sociais foram entrevistados, perfazendo assim, um total de 10 entrevistas com representantes de diversos segmentos como Aterro Sanitário do ASMOC, Usina de biogás GNR Fortaleza-CE, Superintendência Estadual do Meio Ambiente (SEMACE), comunidade do entorno do aterro ASMOC e da Usina GNR, como apresentado na Tabela 3. 
Tabela 3. Classificação dos atores sociais envolvidos na pesquisa.

\begin{tabular}{|l|l|}
\hline \multicolumn{1}{|c|}{ Classificação } & \multicolumn{1}{c|}{ Ator social } \\
\hline Privado & CEGÁS - Usina de biogás \\
\hline Estado & SEMACE - Superintendência Estadual do Meio Ambiente do Ceará \\
\hline Comunidade & $\begin{array}{l}\text { População do entorno do aterro sanitário ASMOC e da usina de } \\
\text { biogás GNR Fortaleza }\end{array}$ \\
\hline
\end{tabular}

A classificação dos atores sociais em três públicos, privado, estado e comunidade, permitiu direcionar melhor este estudo de pesquisa. Assim como, organizar com mais eficiência os questionários e entrevistas, e também, realizar o diagnóstico dos dados da pesquisa.

Nesse sentido, percebeu-se que diversos conflitos socioambientais foram constatados com a instalação e operacionalização do aterro sanitário ASMOC e da usina GNR, a exemplo de geração de emprego e renda, direito do pedestre e ciclista, degradação do solo e a desvalorização dos imóveis locais, ar e água limpos, invisibilidade dos gestores dos referidos empreendimentos, dentre outros. Assim sendo, contatou-se o quanto esses atores sociais do entorno imediato do ASMOC e da GNR foram afetados. Assim como, foi percebido na relação de poder o quanto essa população é invisível à gestão dos dois equipamentos em estudos e, também do poder público.

\section{Considerações finais}

A natureza exige que seja repensada as ações antrópicas em virtude das mudanças climáticas com a grave problemática ambiental, social e econômica como resultado do modelo econômico mundial, pautado no capitalismo financeiro, extrativista e dependente e a relação de poder existente entre o homem e a natureza. Dessa forma, toda e qualquer região do território brasileiro tem a necessidade de se avaliar e monitorar as ações da sociedade na perspectiva da sua relação com os recursos naturais.

Os meios de comunicação no Brasil têm ações de insuficiência na busca por sensibilizar a população sobre a crise ambiental e seus verdadeiros impactos negativos, de modo a compreender que o homem é parte do meio ambiente e a problemática ambiental afeta a todos que compõe o planeta desde o meio antrópico ao meio físico. Com isso havendo interferência direta colocando em risco sua próxima existência e consequentemente afetando as gerações presentes e futuras. Afinal, compreende- se que a crise socioambiental é fruto das ações do homem na sua relação com a natureza e que a própria sociedade encontra grandes dificuldades para mitigar ou superá-la.

Contudo, faz-se necessário a aplicação das leis ambientais a exemplo da Política Nacional do Meio Ambiente e da Política Nacional de Educação Ambiental de forma formal e não-formal com a perspectiva da integração, continuação e permanência com avaliação e monitoramento das ações do homem por meio de indicadores socioambientais nos meios públicos e privados. $\mathrm{O}$ modelo dessas ações de mudança de comportamento inicia-se e deve permanecer em conjunto, ou seja, de forma compartilhada com prazos amarrados e metas bem definidas no processo de mitigação dos impactos negativos.Afinal, somos todos cúmplices e vítimas dessas ações degradadoras, poluidoras, contaminadoras dos meios físico, biótico e antrópico.

Portanto, percebe-se insuficiência na gestão e execução das políticas públicas e na relação dos movimentos sociais na busca pelo enfrentamento dos conflitos socioambientais e suas relações de poder diante da forma da apropriação dos recursos naturais.

Nesta pesquisa tornou-se evidente que os atores sociais mais ricos têm mais acesso e consomem mais a natureza do que os pobres. Nessa relação desigual foi percebido o 
quanto os gestores da usina e do aterro estão ganhando com a venda de biometano gerado na usina, enquanto que a maioria da população do entorno está sofrendo, desamparada, pela injustiça socioambiental.

Por meio da Ecologia Política, tornou-se possível constatar diversos impactos e conflitos socioambientais que muitas vezes são invisíveis aos olhos da sociedade em geral. A Ecologia Política se constitui numa poderosa chave de leitura da realidade local e transformação social.

Portanto, recomenda-se a realização de estudos e pesquisas que averiguem ou monitorem a relação de poder que determinam o acesso e o uso dos recursos naturais no aterro sanitário ASMOC e usina de biogás GNR Fortaleza, como forma, de ampliar a visibilidade necessária para compreensão e solução dos conflitos socioambientais.

\section{Conflito de interesses}

Os autores declararam não haver conflito de interesses.

\section{Referências}

Agamben, G. Homo sacer: o poder soberano e a vida nua. Belo Horizonte: Editora UFMG, 2002.

Bazzicalupo, L. Biopolítica: un mapa conceptual. Santa Cruz de Tenerife: Editorial Melusina, 2016.

Biernack, P.; Waldorf, D. Snowball sampling: Problems and techniques of chain referral sampling. Sociological Methods and Research, v. 10, n. 2, p.141-163, 1981. https://doi.org/10.1177/004912418101000205

Bourdieu, P. 0 poder simbólico. Rio de Janeiro: Bertrand Brasil, 2002.

Brasil. Cidade Brasil/Estado do Ceará/Município de Caucaia. Disponível em: <https://www.cidade-brasil.com.br/municipio-caucaia.2015>. Acesso em: 13 mar. 2021.

Brasil. O que é CONAMA. 2014. Disponível em: <https://www.oeco.org.br/dicionarioambiental/27961-o-que-e-o-conama/>. Acesso em: 25 jan. 2021.

Brasil. Lei no 6.938, de 31 de agosto de 1981. Dispõe sobre a Política Nacional do Meio Ambiente, seus fins e mecanismos de formulação e aplicação, e dá outras providências. Disponível em: <https://www2.camara.leg.br/legin/fed/lei/1980-1987/lei-6938-31agosto-1981-366135-publicacaooriginal-1-pl.html>. Acesso em: 18 jun. 2019.

Brasil. Resolução CONAMA no 001, de 23 de janeiro de 1986. Disponível em: <http://www.ibama.gov.br/sophia/cnia/legislacao/MMA/RE0001-230186.PDF>. Acesso em: 18 set. 2019.

Brasil. Lei no 9.795, de 27 de abril de 1999. Dispõe sobre a educação ambiental, institui a Política Nacional de Educação Ambiental e dá outras providências. Disponível em: <http://www.planalto.gov.br/ccivil_03/leis/19795.htm>. Acesso em: 18 jun. 2019.

Brasil. Resolução CONAMA no 357, de 17 de março de 2005. Dispõe sobre a classificação dos corpos de água e diretrizes ambientais para o seu enquadramento, bem como estabelece as condições e padrões de lançamento de efluentes, e dá outras providências. Disponível em: <http://pnqa.ana.gov.br/Publicacao/RESOLUCAO_CONAMA_ n_357.pdf>. Acesso em: 18 jun. 2020. 
Brasil. Resolução CONAMA no 404, de 11 de novembro de 2008. Estabelece critérios e diretrizes para o licenciamento ambiental de aterro sanitário de pequeno porte de resíduos sólidos urbanos. Disponível em: <http://www.mp.go.gov.br/portalweb/ $\mathrm{hp} / 9 /$ docs/res_conama_404_-_estabelece_criterios_e_diretrizes_para_o.pdf $>$. Acesso em: 18 jun. 2020.

Brasil. Lei no 12.305, de 02 de agosto de 2010. Institui a Política Nacional de Resíduos Sólidos; altera a Lei no 9.605, de 12 de fevereiro de 1998; e dá outras providências. Disponível em: <http://www.planalto.gov.br/ccivil_03/_ato2007-2010/2010/lei/ 112305.htm>. Acesso em: 02 ago. 2020.

Burnley, S. J. A review of municipal solid waste composition in the United Kingdom. Waste Management, v. 27, n. 10, p. 1274-1282, 2007. https://doi.org/10.1016/j.wasman. 2006.06.018

Capra, F. "O Tao da Física" e "A Teia da Vida”: entrevista do físico e ambientalista Fritjof Capra, 1999. Disponível em: <https://www.youtube.com/watch?v=P6-yuMpk6B8>. Acesso em: 20 jan. 2021.

Capra, F. Entrevista concedida a Maria Laudecy Ferreira de Carvalho. Natal, Rio Grande do Norte, 26 jan. 2021.

Carvalho, M. L. F. Políticas de gestão dos resíduos sólidos domiciliares na Cidade de Fortaleza-Ceará: avanços e desafios. João Pessoa: Universidade Federal da Paraíba, 2016. (Dissertação de mestrado).

Centrulo, N. M.; Centrulo, T. B.; Gonçalves D. S. L. F.; Ramos, T. B. Solid waste indicators in local sustainability assessment: A literature review. Ambiente \& Sociedade, v. 23, p. 1-31, 2020. https://doi.org/10.1590/1809-4422asoc20190028r3vu2020L5AO

Ecofor S/A. Relatório de Impacto Ambiental (RIMA): Projeto de Implantação para a Ampliação do Aterro Sanitário Metropolitano de Caucaia-CE. Fortaleza, SEMACE: 2011. Disponível em: <https://www.semace.ce.gov.br/wp-content/uploads/sites/46/2020/ 06/11512641_4_RIMA-ASMOC-VERSAO-FINAL.pdf>. Acesso em: 31 mar. 2021.

Esmaeilian, B.; Wang, B.; Lewis, K.; Duarte, F.; Ratti, C.; Behdad, S. The future of waste management in smart and sustainable cities: A review and concept paper. Waste Management, v. 81, p. 177-195, 2018. https://doi.org/10.1016/j.wasman.2018.09.047

Esposito, R. Comunidad, inmunidad y biopolítica. Barcelona: Herder, 2012.

Exame. Interior de São Paulo ganha sua primeira usina movida a lixo. 2014. Disponível em: $<$ https://exame.com/ciencia/interior-de-sp-ganha-sua-primeira-usina-movida-a-lixo/>. Acesso em: 23 out. 2020.

Fortaleza. Plano Municipal de Gestão Integrada de Resíduos Sólidos Urbanos (PMGIRS). Fortaleza: Fortaleza, 2012.

Foucault, M. A sociedade punitiva: curso no College de France (1972-1973). São Paulo: Martins Fontes, 2015.

Foucault, M. El poder, una bestia magnifica: sobre el poder, laprisión y la vida. Buenos Aires: Siglo XXI, 2012.

Foucault, M. Historia de la sexualidad 1: la voluntad de saber. México: Siglo XXI, 1977.

Foucault, M. Historia de la sexualidad 1: la voluntad de saber. Madrid: Siglo XXI, 2016.

Foucault, M. Microfísica do poder. 7. ed. Rio de Janeiro: Paz e Terra, 2018.

Foucault, M. Vigilar y castigar. México: Siglo XXI, 1976. 
Gonçalves, P. V. S.; Tavares, P. A.; Ferreira, F. N.; Dutra, V. A. B.; Beltrão, N. E. S.; Ferreira Filho, H. R.; Ribeiro, H. M. C. Responsabilidade compartilhada sobre os resíduos sólidos e educação ambiental no contexto urbano amazônico. Revista Brasileira de Educação Ambiental, v. 14, n. 4, p. 360-373, 2019. https://doi.org/10.34024/revbea.2019.v14.2725

Guerrero, L. A.; Maas, G.; Hogland, W. Solid waste management challenges for cities in developing countries. Waste Management, v. 33, n.1, p. 220-232, 2013. https://doi.org/10.1016/j.wasman.2012.09.008

Gumbowsky, A.; Treml, K. S.; Juraszek, L.; Ossig, V. D.; Marchesan, J.; Bazzanella, S. L. As relações de poder e os reflexos ao meio ambiente e à vida. Desenvolvimento Regional em Debate, v. 9, p. 506-520, 2019.

Güttrón Torres, R. Biopoder, psicopoder y ecopoder. Revista Desenvolvimento e Meio Ambiente, v. 54, p. 26-39, 2019.

Han, B.-C. Psicopolítica. Barcelona: Herder, 2018.

Han, B.-C. Sobre el poder. Barcelona: Herder, 2016.

Leff, E. La apuesta por la vida: imaginación sociológica e imaginarios sociales en los territorios ambientales del Sur. México: Siglo XXI, 2014.

Leff, E. Racionalidad ambiental. México: Siglo XXI, 2009.

Lipietz, A. A ecologia política e o futuro do marxismo. Ambiente \& Sociedade, v. 5, n. 2, n. 2, p. 9-22, 2003. https://doi.org/10.1590/S1414-753X2003000200002

Marcuse, H. Razón y revolución. Madrid: Alianza, 2003.

Martinez-Alier, J. Macroeconomia ecológica, metabolismo social e justiça ambiental. Revista História Atual, v. 9, n. 9, p. 149-168, 2011.

Medieta, E. "Hacer vivir y dejar morir": Foucault y la genealogía del racismo. Tabula Rasa, v. 6, p. 138-152, 2007.

Mitzman, A. La jaula de hierro: una interpretación histórica de Max Weber. Madrid: Alianza, 1976.

Naredo, J. M. Raíces económicas del deterioro ecológico y social: más allá de los dogmas. Madrid: Siglo XXI, 2007.

Naves, F. L. Saberes, poderes e os dilemas das relações socioambientais. Organizações Rurais e Agroindustriais, v. 6, n. 2, p. 121-133, 2004.

Ojaide, T. No tienes que ser. In: WPM - World Poetry Movement. Antología Internacional de Poemas para la Justicia Social em el Mundo. 2013. Disponível em: <https://www.wpm2011.org/es/node/363>. Acesso em: 21 abr. 2019.

Ortiz de Landázuri, M. C. De la biopolítica a la psicopolítica en el pensamiento social de Byung-Chul Han. Athenea Digital, v. 17, n. 1, p. 187-203, 2017.

Osorio, J. Biopoder y biocapital. Argumentos, v. 19, n. 52, p. 77-98, 2006.

PDDU/CAUCAIA. Plano Diretor de Desenvolvimento Urbano de Caucaia: municípios limites da Cidade de Caucaia. Disponível em: <http://salasituacional.fortaleza.ce.gov.br: 8081/acervo/documentById?id=39c878e3-2316-4471-a7c3-47e03bee16f0>. Acesso em: 30 jun. 2021.

Santos, B. S. A crítica da razão indolente: contra o desperdício da experiência. São Paulo: Cortez, 2000. 
Santos, B. S. Pela mão de Alice: o social e o político na pós-modernidade. São Paulo: Cortez, 1999.

SEMACE - Superintendência Estadual de Meio Ambiente. Licenciamento ambiental. 2019. Disponível em: <https://www.semace.ce.gov.br/wp-content/uploads/sites/ 46/2020/06/11512641_4_RIMA-ASMOC-VERSAO-FINAL.pdf>. Acesso em: 27 mar. 2021.

Vincent, A. Ideologias políticas modernas. Rio de Janeiro: Jorge Zahar, 1995. 